\title{
ANATOLIAN LANGUAGES AND PROTO-INDO-EUROPEAN
}

\section{LENGUAS ANATOLIAS Y PROTOINDOEUROPEO}

\author{
Ignasi-Xavier Adiego \\ Universitat de Barcelona \\ ignasi.adiego@ub.edu
}

DOI: $10.1387 /$ veleia.16819

\begin{abstract}
This paper is a state of the art report on the dialectal position of the Anatolian group (which comprises Hittite, Luwian, Palaic, Lycian, Milyan, Carian, Pisidian and Sidetic) within the Indo-European linguistic family. It evaluates the two main positions which have hitherto tried to explain the strong divergence between the Anatolian languages and the reconstructed Proto-Indo-European linguistic stage: on the one hand, there is the hypothesis which assumes a general process of loss of linguistic categories in Anatolian; on the other, we have the hypothesis which assumes an early separation of Anatolian from the common language. In this regard, I will point to some biased opinions about linguistic change which have conditioned this discussion. As well as that, I will emphasize the progress in the study of the Anatolian languages other than Hittite, and their contribution to the question on the dialectal position of Anatolian in the Indo-European group. The conclusion is that the present situation makes it difficult to decide which of the two positions discussed is right.

Keywords: Proto-Indo-European, Anatolian Languages, Hittite, Indo-European subgrouping.
\end{abstract}

Resumen: En el presente artículo se ofrece un estado de la cuestión sobre la posición del grupo anatolio (hitita, luvita, palaíta, licio, milio, lidio, cario, pisidio y sidético) en el seno de las lenguas indoeuropeas. Se someten a evaluación las dos grandes corrientes de opinión que han intentado dar cuenta de las fuertes divergencias entre las lenguas anatolias y el protoindoeuropeo reconstruido: la hipótesis de la pérdida de categorías en anatolio y la hipótesis de una separación temprana del anatolio. En el marco de esta evaluación se señalan algunos prejuicios y apriorismos sobre el cambio lingüístico que han condicionado innecesariamente el debate. También se hace énfasis en el progreso alcanzado en el estudio de las lenguas anatolias diferentes del hitita, lo que ha permitido incorporarlas a un debate que en principio se limitaba a confrontar el hitita con el proto-indoeuropeo. El artículo concluye señalando que en este momento resulta difícil decantarse a favor de una u otra hipótesis.

Palabras clave: proto-indoeuropeo, lenguas anatolias, hitita, sub-agrupación indoeuropea.

Recibido: 1-12-2015

Informado: 8-05-2016

Definitivo: 22-05-2016

$\$ 1$. The irruption of Hittite (and consequently Anatolian group, from which Hittite is the best known dialect) into the Indo-European studies was undoubtedly an extraordinary event, but 
it must be admitted that it took place at a very inopportune moment. The two seminal works of Friedrich Hrozný (Hrozný 1915, 1917) that, after Knudtzon's pioneering work (Knudtzon 1902), definitively demonstrated the adscription of Hittite to the Indo-European family, seem to surround threateningly the appareance in 1916 of the last volume of the definitive edition of Brugmann's and Delbrück's Outline of the Comparative Grammar of the Indo-European Languages (Grundriß der vergleichenden Grammatik der indogermanischen Sprachen), originally meant to be the crowning achievement of the reconstruction of Proto-Indo-European (henceforth PIE) (Brugmann-Delbrück 1886-1900, 1897-1916). Karl Brugmann, the author of the phonological and morphological reconstruction (the most extensive part of the Grundriß) presented the outcome of the historical-comparative method applied to the comparison of Indo-European languages and the reconstruction of the proto-language considered as their common source.

For obvious reasons, Hittite could not be included in this monumental undertaking, and as early as in 1921 Emil Orgetorix Forrer noted that Hittite created a serious problem for the Brugmannian model (Forrer 1921). Since this study by Forrer, the dialectal position of Hittite and, therewith, Anatolian within the Indo-European linguistic family has been much debated and, no doubt, it will be a matter of discussion for future generations.

$\$ 2$. Before considering the main positions on the question of the relationship between Anatolian and the remaining Indo-European languages, it is important to stress that, a century after Hroznýs seminal paper on Hittite, Anatolian linguistics has undergone a drastic and spectacular development. In other words, a century after the bare statement that Hittite is an IE language, we are now in a position in which we can state that various IE languages were spoken in most parts of Asia Minor (Anatolia, the modern Turkey) during at least more than two millennia. Most of these attested languages constituted a particular Indo-European dialectal group known as Anatolian ${ }^{1}$.

Therefore, I think that it is of interest to explain succinctly this development of Anatolian linguistics.

We can see Anatolian linguistics today as the result of the confluence and interaction of four research lines that began independently, and that finally have converged to offer us an overall vision of this Anatolian Indo-European linguistic group.

The first field of research is, obviously, the study of the Anatolian languages present in the cuneiform tablets of the archives of Hittite Kingdom (mostly from the capital city, Hattussa). Among these dialects, Hittite, the official language, still has the lion's share in Anatolian studies, given the great volume of documentation in comparison with the rest of dialects. After the somewhat awkward etymological methodology used by Hrozný, the more rigorous and philology-based method of scholars like Ferdinand Sommer and others involved a considerable advance in the interpretation of Hittite texts and consequently in the knowledge of the vocabulary and grammar of this language, the sole way to undertake later a comparative work. The philological approach has permitted also to refine remarkable aspects such as dating and subsequent chronological layering of Hittite. Nowadays, we have at our disposal extraordinarily valuable tools for the linguistic study of Hittite: aside from textual corpora, there are etymological dictionaries (Tischler 1977-, Puhvel 1984-, Kloekhorst 2008), descriptive grammars (Hoffner-Melchert 2008), lexicographic enterprises (Chicago Hittite Dictionary [CHD], Hethitisches Wörterbuch [HW]), among many

1 The exception is Phrygian, an Indo-European but non Anatolian language documented in central Minor Asia during the first millennium BC. 
other studies on various linguistic aspects. However, Hittite is not the only IE Anatolian Language in the cuneiform tablets of the Hittite Kingdom, where two other dialects, Palaic and Cuneiform Luwian, are also attested. It was also Forrer who detected the presence of these two dialects (Forrer 1919), and since then they have been studied carefully. For Luwian, see Melchert 2003, Yakubovich 2010; for Palaic, see Carruba 1970.

The second research line focuses on the texts (mostly stone inscriptions, but also seal stamps and some lead strips) engraved in a particular script, known as Anatolian hieroglyphic writing. These documents were linked to the Hittites mentioned in the Bible by Archibald Sayce when Hattusa was still undiscovered (Sayce 1877, 27-29). The decipherment of the writing was a slow process undertaken by different scholars (note particularly names like Theodor Bossert, Ignace J. Gelb, Piero Meriggi or Emmanuel Laroche, among others) and gave a shocking new turn when a new decipherment of some few but highly frequent signs was proposed by John D. Hawkins, Anna Morpurgo-Davies and Günter Neumann in 1973 (Hawkins-Morpurgo-Neumann 1973). This new decipherment showed clearly that the language of the hieroglyphs was Luwian (whence the new name 'Hieroglyphic Luwian', now universally accepted). This Luwian dialect was therefore used as an official language in the stone monuments of the last Hittite kings and reappeared as the language of the so-called Neo-Hittite kingdoms in North Syria after the fall of the Hittite Empire. The publication in 2000 of the monumental edition of the corpus of the Hieroglyphic Luwian inscriptions of the Neo-Hittite kingdoms, a masterwork by J. D. Hawkins, has given a great impetus to the study of this Anatolian dialect (Hawkins 2000).

The third research field has focused on the Anatolian dialects conserved in alphabetic writing at the same time as Classical Greek: Lycian, Milyan (a dialect closely related to Lycian), Carian, Lydian, Sidetic and Pisidian. Some of them were already known to the scholars well before the discovery of Hittite. For instance, Lycian and Carian inscriptions were discovered during the 19th century, giving rise to various decipherment proposals and comparative approaches. In particular, in the edition of the Lycian inscriptions by Kalinka 1901, the Lycian alphabet appears already as essentially deciphered. Lycian was first related to Hittite by scholars such as Pedersen (1945), and later to Luwian thanks to a series of very influential articles by Laroche (1957-58, $1960,1967)$. At the present moment, we have very useful tools for Lycian: there are dictionaries (Melchert 2004a and the etymological glossary by Neumann-Tischler 2007), an editio minor available online (Melchert 2001) as well as numerous articles on different phonological, morphological and syntactic problems. A synthesis on Lycian grammar can be read in Melchert (2004b).

In the case of Carian, the definitive decipherment did not occur until the 90s of the 20th century, as a result of which it became clear that it is a language close to Lycian and Luwian too (see Adiego 2007). The same can be said of Pisidian and Sidetic if one judges from the - very few and scarce- extant texts. For Pisidian, see Brixhe (1988), Adiego (2012); for Sidetic, Nolle (2001), Pérez Orozco (2007).

Lydian, however, known particularly from the beginning of the 20th century thanks to archaeological campaigns in Sardis, occupies a particular position in the Anatolian group. On Lydian see Gusmani (1964-1986), Melchert (2004c), Gérard (2005) and references given there.

Finally, the fourth field of research is on the indirect documentation, i.e. glosses and proper names known from very different sources (particularly Greek, but also Latin and Akkadian). The onomastic attestations in the Greek and Roman sources were already studied in the 19th century, and it was a merit of Paul Kretschmer (Kretschmer 1896) to state correctly that (1) all these names belonged to a single linguistic group and (2) that this group was sui generis, that is to say, that it was not a part of Iranian, or Semitic or any other language family or sub-family which was 
already known at that time. It is true that Kretschmer was wrong in considering this group as nonIndo-European, but this mistake is understandable at a moment in which Hittite documents were still not available. As Anatolian languages became accessible and were studied, and also the Hittite and Luwian names were collected, the evidence for a linguistic continuity in the onomastic system became clearer: note, in this sense, the important contribution by Houwink Ten Cate (1965), among others which could be mentioned here. Now, we can see how Anatolian god names such as Arma-, the Mon-God or Tarhunt-, the Storm-God attested during the Hittite Kingdom, are still preserved in a Carian inscription engraved a millennium later under the form of a compound name $a r m o=t r q \delta o-($ Adiego 2007). The literature on the onomastic material is also impressive: the books on place and personal names in classical sources by Ladislav Zgusta (Zgusta 1964, 1971, 1984) or the repertoire of Hittite and Luwian personal names by Laroche (Laroche 1966) continue to be indispensable tools, even though of course they need to be updated with later finds and revisions. For place names in Hittite sources, Tischler-Del Monte (1978) is the reference work. The foundations for a rigorous and systematic analysis of Anatolian personal names inside Anatolian linguistics have been laid recently by Melchert in a short paper destined to be very influential (Melchert 2013).

Also in this research line one must take account of the Anatolian linguistic materials (i.e. proper names, but also common vocabulary) contained in the Old Assyrian tablets from Kaneš that attest the activity of Assyrian merchants in Central Anatolia ca. 2000 BC, which constitute therefore the oldest linguistic samples of an Anatolian dialect and consequently of an Indo-European group (see Dercksen 2007). Note, to quote just one example from these ancient linguistic attestations, the personal name Tarhudasu / Tarhutasu, obviously containing the above mentioned theonym Tarhunt-.

The resulting picture of the Anatolian languages at the present moment is certainly not complete, since there are still too many chronological and geographical uncertainties, but it is at least very rich and unimaginable hundred years ago. Besides Hittite, spoken originally in Central Anatolia and converted into the official language of the royal archive of the Hittite Kingdom, we recognize now another branch of Anatolian, the so-called Luwic group, where Luwian -Cuneiform and Hieroglyphic_-, Lycian, Milyan, Carian and very probably also Sidetic and Pisidian must be included. The dialects of this group share a series of common traits, but it is presently difficult to establish which of these traits point to a unique origin (a Proto-Luwic phase) or to contact. The Anatolian language family is completed by Palaic and Lydian, that constitute independent branches. Moreover, Lydian shows very peculiar characteristics that situate it in a very isolated position in the interior of Anatolian family. As Melchert (forthcoming) points out, nowadays the discussion about the position of Anatolian, which in past years focused exclusively on Hittite, must take into account these other dialects.

$\$ 3$. From the paper by Forrer, in which the idea was cursorily suggested that Hittite occupies a special dialectal position among the Indo-European languages (Forrer 1921), to the still unpublished status quaestionis by $\mathrm{H}$. Craig Melchert (Melchert forthcoming), one of the most relevant scholars on Anatolian, the problem of the relationship between the Anatolian languages and PIE has been dealt with in innumerable publications, where very divergent hypotheses have been formulated $^{2}$. Although this is a well known question for Indo-Europeanists, I think that it is op-

\footnotetext{
2 I refer to Melchert (forthcoming) for an extensive literature about this topic.
} 
portune to recall the main points of the controversy. As mentioned at the outset, the monumental Grundriß by Karl Brugmann and Berthold Delbrück was published in 1916 and, leaving aside some minor problems and discrepancies, the reconstruction offered by those two scholars presented a consistent image of what that proto-language could have been from the comparison of the ancient IE languages. We can synthesize the main features of this reconstruction as follows.

1. The reconstruction of nominal morphology involved:

- a system with three categories, gender, number and case. These categories consisted of three genders (masculine, feminine, neuter), three numbers (singular, dual, plural) and eight cases (nominative, vocative, accusative, genitive, ablative, dative, instrumental, locative).

- from a formal point of view, a system of stems characterized by the final sound of the $s^{3 t e m}{ }^{3}$. A general opposition between $o$-stems and athematic stems was assumed. The $o$ stems, also called thematic stems, are characterized by a thematic vowel -ole-, fixed or non-mobile stress and the absence of apophonic or ablauting alternances, whereas the athematic stems are characterized by apophonic alternances and in many types by mobile stress. Within the athematic stems, an important subclass is constituted by the $\bar{a}$-stems, which mostly express feminine gender and which have developed a particular set of inflectional endings.

- for the adjectives, the expression of gradation by means of specific suffixes. In the case of the comparative degree, a suffix *-ies-/-ios- could be safely reconstructed.

2. The reconstruction of verbal morphology involved:

- a system of three stems (tri-thematism), to wit, present, aorist, perfect, based mostly - but not exclusively - on the expression of aspect. Each stem was formed from the verbal root by means of different characteristic procedures with a particular variety of constructions for the present stems (radical, reduplicated, with nasal infix, with different suffixations) vs. a more limited variety for the aorist stem (radical, sigmatic, reduplicated) and a practically exclusive formation for the perfect stem (the reduplicated perfect). Also remarkable was the existence of a clear-cut differentiation between thematic vs. athematic stems, with characteristics similar to the corresponding nominal stems (invariability of the forms in thematic inflection vs. apophonic and accentual variability in athematic inflection).

- the existence of the voice distinction between active and medio-passive, the number distinction between singular, dual and plural, as well as the distinction between first, second and third person, all of them expressed by means of personal endings.

- the use of different personal endings added to the stem of the present indicative as a means of distinguishing between present and past (the so called imperfect).

- the existence of the indicative, subjunctive and optative moods, the two latter expressed by means of overt suffixes attached to the stem.

- the existence of an imperative mood characterized by the use of specific personal endings.

${ }^{3}$ In the 20th century, Indo-European Linguistics has granted a more preponderant role to vocalic gradation and stress in the establishment of nominal (and also verbal) stem classes, but the distinction between thematic and athematic inflection continues to be essential. 
- the use of a particular set of endings for the perfect stem.

- the presence of the augment in some languages as a trait for past time, opposed to the use without augment for the so-called injunctive mood.

- the absence of any formal expression of future tense, replaced by the use of present pro futuro ${ }^{4}$.

Both nominal and verbal morphology was characterized by the existence of "portmanteau" morphemes, typical for inflectional languages, so that a morpheme expressed different categories. Likewise, some categories were expressed simultaneously by means of different morphemes or formal variations. Take, for instance, the PIE 3rd person singular optative present of the active voice ${ }^{*}$ sièt [Brugmannian reconstruction], from the verbal root ${ }^{*} s-/ s-$ 'to be': the ending ${ }^{*}-t$ expressed at once active voice (vs. the ending of medio-passive voice), 3rd person, singular number, and the optative character of the form; in the indicative mood, this ending ${ }^{*}-t$ expressed a tense opposition between past ${ }^{*}-t$ vs. present ${ }^{*}-t i$, but in the optative it was the obligatory ending. The suffix *-ié- was the marker of optative mood required for the singular forms (vs. the form used in plural, namely $\left.{ }^{*}-i-\right)$ of an athematic stem. Finally, the form of the stem ${ }^{*} e s-/ s$ - indicates the form belongs to the present system, and not to aorist or to perfect.

It is therefore impossible to say, unlike in agglutinative languages, that such or such morpheme expressed exclusively such or such category. It is the combination of the different morphemes (in this case ${ }^{*} s-{ }^{*}-i \bar{e}$ - and $\left.{ }^{*}-t\right)$ what gives its specific inflectional nature to this form ${ }^{*}$ sie t, a 3rd singular person active of the optative of the present stem of the verb *es-/s-.

This reconstruction by Brugmann and Delbrück was firmly based on the comparison of the main ancient Indo-European languages. For instance, the verbal system with three stems (present / aorist / perfect) was clearly drawn from its parallel survival in Sanskrit and Greek, and in the case of Latin, where the verbal system was organized around only two stems (present / perfect), it was easily demonstrated that the perfect stem was the result of the convergence of the PIE aorist and perfect. According to this view, the absence in a particular language of any morphological category and/or the corresponding morpheme reconstructed for the PIE was interpreted as the result of the loss of that category and/or of that morpheme with the subsequent reorganization of the system. Therefore, the fact that Latin or Germanic lack a three-stem verbal system was explained as the consequence of a reduction or syncretism of the PIE perfect and aorist stems into a unified stem, which is called preterite in Germanic and perfect in Latin. If no traces of a sigmatic aorist can be observed in Germanic, the only explanation was that the above reduction implied the absolute loss of the $-s$ aorist and of all possible sigmatic aorist stems, even those that could have survived as fossilized or quasi-fossilized formations (as it does occur in Latin, where old sigmatic aorists still constitute a sub-class of perfect stems). To attribute the absolute absence of sigmatic aorists in Germanic to a special position of Germanic inside the Indo-European family was unimaginable.

Certainly, this reconstruction was not without problems. One of the possible problematic cases was the augment: Indo-Iranian and Greek, as well as other IE languages which are less decisive for reconstruction, such as Armenian and Phrygian, coincided in having this prefix for marking past tense, but it was absolutely absent in the remaining IE languages. The presence of augment in the two pillars of the PIE verb reconstruction - Sanskrit and Greek- encouraged reconstruct-

${ }^{4}$ For some authors, the subjunctive mode was actually a future in PIE, see now Bozzone (2012). 
ing it for the proto-language. It must be said that, from the point of view of traditional PIE reconstruction, the problem has not been satisfactorily resolved. The augment has been usually considered as an innovation which occurred in a limited area within Indo-European, but it is true that, given its occasional omission and its tendency to disappear even in the languages that showed it, it is equally possible that it existed in PIE and that it was lost in most dialects. See Szemerényi 1996, 296-299 for this discussion.

A further point which gave rise to discussions in Brugmann's model was the particular position of feminine gender. The fact that the *-äl-a that characterizes (in Brugmann's reconstruction) the feminine inflection was formally identical to the plural neuter ending, considered originally a collective marker, paved the way to speculations about a more recent development of the feminine gender, a view later reinforced by Hittite itself (see below).

$\$ 4$. Evidently, these problems are peccata minuta compared with the earthquake caused by the simple comparison of Hittite morphology to Brugmann's reconstructed PIE:

1. The nominal inflection was very different from the PIE proposed before the interpretation of the Hittite language:

- Hittite has two genders ('commune' and 'neutrum') without any trace of the feminine gender, either in substantives or in adjectives.

- there is no dual.

- a unique set of case endings is used for all the nominal stems, so that we cannot properly speak of 'thematic' stems and of $\bar{a}$-stems as inflections differentiated from the rest of athematic inflections.

- no traces of adjectival gradation can be observed.

2. In the verbal inflection, the Anatolian situation is even more deviant from the Brugmannian reconstruction:

- there is not tri-thematism: there is only one stem form from which all the conjugation for each verb is created. Against the present-aorist-perfect system of Brugmannian PIE, Hittite shows a monothematic system.

- even more interestingly, there are no clear traces at all of the markers of aorist and perfect stems.

- there are only indicative and imperative moods. No traces of optative and subjunctive exist.

- each verb belongs to one of two conjugation classes, the so-called mi-conjugation and $h i$ conjugation, and these classes are characterized by a partially different set of inflectional endings. The criteria by which primary and derived verbs were assigned to one or another class remain unclear. Whereas the endings of the mi-conjugation are easily compared to the primary and secondary endings of Brugmannian PIE, the singular endings of the hi-conjugation show evident connections to the Brugmannian PIE perfect and middle endings, but it is formally impossible to think of the hi-class as the outcome of a simple 'reconversion' of PIE perfects or middles into a class conjugation.

— similarly to the Brugmannian model, Hittite distinguishes between present and past by means of personal endings.

- The existence of two voices expressed by means of the personal endings is also common with the Brugmannian model. 
- Hittite shows particular means of expressing mood and aspect: it developed a periphrastic perfect, it used suffixes such as -skelska-for deriving stems with imperfective meaning or it resorted to particles for expressing modal nuances (potential, irreal, optative).

— Hittite has neither dual nor augment.

3. It is also very noteworthy that a kind of nominal stem formation taken as residual in Brugmannian PIE — the heteroclite - $r / n$ - stems — was fully productive in Hittite and Luwian.

It is important to note that the increasing knowledge of Anatolian dialects other than Hittite has led to the modification of some ideas based exclusively on Hittite data. An excellent example of this is the fact that Lycian shows a clear differentiation between $a$-stems (coming from PIE ${ }^{*}-e h_{2}$-stems) and $e$-stems (coming from the thematic inflection, most of them secondarily converted in $e / i$-stems as a consequence of the so-called $i$-mutation). Consequently, the single nominal inflection found in Hittite is the result of a unification of the original $e h_{2^{-}}, o-$ and other PIE stems, mainly due to the phonological merger of $\mathrm{PIE}^{*} o$ and ${ }^{*} \bar{a}$ in Hittite $a$, a vowel which was long or short depending on its stressed or unstressed character respectively. On the Lycian $a$-stems, see below.

$\$ 5$. Faced with the need of reconciling these important differences between Brugmannian PIE and Hittite, Indo-Europeanists have resorted to two main hypotheses:

1. the 'Schwund'- (or 'loss'-) hypothesis. According to this hypothesis, Anatolian is another branch of PIE, and the differences from the Brugmannian model of PIE must be attributed to the loss of categories and their corresponding markers.

2. that traditionally known as the 'Indo-Hittite'-hypothesis. In this view, Anatolian is a sister branch of PIE, both coming from a protolanguage labeled Indo-Hittite. Other authors use a different term for this proto-language, but this is not relevant here. This traditional formulation has been nowadays reworked into a more nuanced version, known as the 'Early Separation'-hypothesis, which assumes that Anatolian was the first group to be separated from PIE, though this does not mean that all the differences between PIE and Anatolian must be explained as a consequence of this early separation.

Only the innovations common to the rest of Indo-European branches but not shared by Anatolian must be considered as belonging to a post-Anatolian PIE, and a careful scrutiny has to be undertaken in order to find these innovations that can serve as a proof of an early separation.

The 'Schwund'-hypothesis implies that Brugmannian reconstruction does not need to be questioned. One must simply assume that Proto-Anatolian inherited categories such as the presentaorist-perfect, the optative, and the feminine, and that it lost all of them, in the same manner as, for instance, French or Modern English have lost the case system of Latin and Old English, respectively.

$\$ 6$. Some criticisms of the 'Schwund'-hypothesis are based on an impressionistic approach to language evolution and, despite their popularity, are very weak. Firstly, this hypothesis has been associated with a 'conservative' or 'old-fashioned' view of PIE by the fact that it leaves the Brugmannian reconstruction of PIE basically unaltered. But Brugmannian reconstruction was rigorously based on the comparative method and it is able to assimilate without special difficulties a process of loss of categories and markers in a particular branch. As it is well known, in Historical Comparative linguistics what is difficult is to explain the apparition of new elements such as phonemes and morphemes, not the loss of them. The label 'conservative' seems to imply other connotative —and derogative nuances alien to strictly linguistic discussion. 
Another typical objection to the 'Schwund'-hypothesis is the lack of time for the transformation which must be assumed for Anatolian. The idea that it is possible to establish absolute chronologies for the evolution of a language is a locus communis not supported by clear evidence. It combines with another atavistic idea, coming from the times in which the chronological periods proposed for Prehistory were short, and according to which there was no material time for this alleged radical transformation from Brugmannian PIE to Anatolian. The insistence on Hittite as the oldest attested Indo-European language can give us an exaggerated impression of archaism -in fact, the first direct attestations of Hittite are only a few centuries older than Mycenaean Greek.

I think that the previous criticisms involve an abuse of the methodological principle known as antiquior melior. This principle is logical when we have to establish the relevance of different phases of the same dialect for the reconstruction of the protolanguage. For instance, for the reconstruction of PIE it is better to use Latin and Old English than French and Modern English respectively, because we assume logically that the phase attested earlier is closer to the protolanguage. This is an obvious fact when dealing with different phases of the same dialect, but it does not serve for different dialects. Take for instance the nominal inflection in Shakespeare's English and contemporary Icelandic: although Shakespeare's English is 400 years older than contemporary Icelandic, it is clear that the latter is closer to the Proto-Germanic linguistic situation. However, a simple comparison of the nominal inflection of contemporary Icelandic and Shakespeare's English, accompanied by the fallacious application here of antiquior melior, would force us to assume that English separated from Proto-Germanic before this had developed the case system observed in Icelandic. The fortunately well attested Old English contradicts absolutely this supposition.

The chronological distance between Old Hittite (17th-16th centuries BC) and Mycenaean Greek (1425-1200 BC) is less than that of the example just referred to. Therefore, in absence of other dialects directly attested in the same time span, there is no reason to assume that the differences between the simpler and more analytical Hittite verbal system and the more complex and more synthetic verbal system which can be assumed for Mycenaean Greek are due to an early separation of Hittite (and Anatolian) before the development of the verbal system reconstructed in the Brugmannian PIE.

It is noteworthy how tempting is the resort to the fallacy of the 'lack of time': even a scholar as serious as Jay Jasanoff uses it as an argument against the "perfect theory", i.e. the derivation -in line with the 'Schwund'-hypothesis - of the Anatolian - hi conjugation from the PIE perfect. Against the possibility that this 'perfect theory' can use the loss of reduplication in Germanic preterits coming from PIE perfects to justify that there are no reduplication stems in the Anatolian hi-conjugation, Jasanoff states the following argument: "But the parallel between the two branches [scil. Anatolian and Germanic] cannot be pressed too far. Late Proto-Germanic was spoken a few centuries before the beginning of the Christian era, a full two thousand years later than Proto-Anatolian. Nowhere among the 'classical' IE dialects was the perfect stripped of its reduplication with greater consistency than here; yet even here the tenacity of reduplication in the perfect is shown by the survival of nearly two dozen reduplicating strong verbs in Gothic alone (e.g. letan 'let', pret. lailot, haitan 'order', pret. haihait. etc.). If the hi-conjugation in fact grew out of the perfect, it would have to have given up its reduplication with a precocity unmatched in any other IE language" (Jasanoff 2003,16; italics are mine). It seems that, in this quote, Jasanoff is assuming a sort of absolute chronology for the loss of the perfect reduplication in the IE languages, a simply absurd assumption.

It is also fallacious to associate the 'simpler' morphology of Hittite (in comparison to that of Brugmaniann PIE) to a 'primitivism', as in the following sentence from Zeilfelder $(2001,11)$ : "Der Eindruck einer gewissen Primitivität des anatolischen Formenbestandes drängt sich unmittel- 
bar auf" ('The impression of a certain primitive character in the formal situation of Anatolian imposes itself immediately'). Ironically, these allegedly primitive features are occasionally interpreted by some authors as 'modern' features! Cf. Sturtevant $(1926,32)$ : "We are therefore confronted with the paradox that the oldest known Indo-European language shows a very advanced stage of development in vocabulary, morphology and phonology. The hypothesis of extensive contamination with other languages has been advanced by several scholars; but that can account only for the composite nature of the vocabulary. The most serious difficulty is presented by the curiously simple and modern yet Indo-European inflection of this very ancient language." [Italics are mine].

We are dealing here with two opposed ways of interpreting language simplicity in 'glottogonic' terms, both of them purely speculative: on the one hand, there is the idea that earlier languages were more complex, more 'perfect' (Classical Sanskrit being the perfect illustration of this conception of perfect language); on the other, there is the idea that earlier languages are simpler, more 'primitive' (of course, as a reflex of a more primitive mind). Now we know that the languages can change from more synthetic to more analytical systems, and they can return to synthesis and so on.

We know also that system collapses can be attributed to sociolinguistic factors (note the hypothesis of Trudgill 2010, 1-35 about the evolution of English), or merely to internal phonological alterations, as in the case of the loss of final sounds in Vulgar Latin or Late Old Persian, which caused deep changes in the morphological paradigms. Therefore, the typological features of a language cannot be interpreted as more or less 'archaic', more or less 'modern', more or less 'perfect' or the like. In consequence, it is therefore impossible to draw any conclusion about the chronological position of Anatolian regarding PIE on the basis of merely typological considerations.

$\$ 7$. If we put aside all these fallacious criticisms, we could assert that, in principle, any alternative to the 'Schwund'-hypothesis must offer an attractive and consistent explanation of how Common Post-Anatolian Indo-European developed the innovations not shared with Anatolian. In other words, the burden of proof ought to be in the hands of the hypothesis which assumes an 'early separation', i.e. the traditional 'Indo-Hittite'-hypothesis. I recognize that this assertion can seem too strong but in my opinion it is consistent with the theoretical framework of Comparative-Historical Linguistics. It is easily exemplified in the reconstruction of the PIE vowel system: if one would wish to return to Schleicher's reconstruction, proposing therefore that PIE only had the vowels $*_{i}{ }^{*} a,{ }^{*} u$ (short and long), one ought to explain why the PIE ${ }^{*} a$ became in Greek or Latin three different vowels (i.e. $>e, o, a$ ).

However, if one defends the reconstruction of the PIE vocalism with ${ }^{*} i,{ }^{*} e,{ }^{*} a,{ }^{*} o$ and ${ }^{*} u$, one would be not forced to justify why ${ }^{*} a,{ }^{*} e,{ }^{*} o$ became one vowel $(>a)$ in Sanskrit. Similarly, it is more difficult to explain how the feminine gender or the optative mood appeared as common post-Anatolian innovations than to assume a loss of these categories in Anatolian.

Of course, this strong assertion is only valid for those cases where Hittite (and Anatolian) shows a loss of categories. The position of the 'Schwund'-Hypothesis is much more inconvenient when it must explain the emergence of new categories, particularly if these new categories seem to 're-use' PIE markers. The most emblematic example of this situation is provided by the mentioned $h i$ conjugation of Hittite. There is general agreement among the specialists in that the endings of this class are closely related to the PIE perfect and middle endings, but, as it was pointed out above, it is impossible to trace the origin of hi-conjugation directly from the PIE perfect ${ }^{5}$. Any version of

\footnotetext{
5 An origin from middle would be less probable, because Anatolian maintains the PIE middle.
} 
the 'Schwund'-hypothesis ought to offer a persuasive model of development that can explain how a new conjugation emerged from the recycling of the endings of the old system. As Jasanoff (2003) shows, the different attempts to achieve this are unconvincing (see below $\$ 9$ ).

Despite that Melchert (1998) and (forthcoming) seems to present 'Indo-Hittite' and 'early separation' as two different hypothesis, I think, following Zeilfelder, that the latter is a refinement —indeed, a very elaborated one - of the former. The Indo-Hittite hypothesis, in its original and rather rough formulation, attributed all the peculiar traits of Hittite to the nebulous Indo-Hittite and left unaltered the Brugmannian PIE. We could synthesize that in a formula such as: Indo-Hittite $=$ Brugmannian PIE minus Anatolia. This was a model strongly criticized because it has been unable to explain where all the Post-Anatolian common innovations came from: as we have mentioned above, in the framework of Historical-Comparative Linguistics it is difficult to assume that all the categories that would differentiate Anatolian from post-Anatolian IE developed from nothing.

As pointed out above, the 'early separation'-hypothesis has tried to give an answer to these objections by checking, point by point, all the differences between Anatolian and non-Anatolian PIE in order to establish clearly which of these differences must be considered common innovations of a "post-Anatolian" Indo-European, and which others are explainable in another manner. Of course, it is important to take account of a possible dilemma: (1) if we are able to establish at least one innovation common for a "post-Anatolian" Indo-European, and not a trivial one, an early separation ought in principle to be assumed, but (2) if the booty is quantitatively scarce, the idea of an early separation can hardly be accepted only on the basis of the absence of one category (or a few categories) in Anatolian.

$\$ 8$. Rieken (2009) and Melchert (forthcoming) are two recent and very serious attempts to detect these post-Anatolian common innovations (in the case of Rieken conversely expressed as 'Anatolian archaisms'). The lists of probable common innovations attained by both scholars are very modest. Rieken establishes as worthy of consideration a short list of Anatolian "archaic" traits: [1] lack of feminine gender; [2] lack of adjectival gradation, [3] lack of optative and subjunctive moods; [4] ending -os for dative-locative plural, [5] ${ }^{*}-s$ as morpheme of 2 sg preterite (vs. its extension as aorist marker in the rest of IE languages), [6] the hi-conjugation. Here we find the two typical cruces of the problem: the feminine and the verbal system (represented by traits 3,5 and 6 ) are considered along with other very secondary phenomena.

Rieken opportunely notes that the morphemes involved in [1], [2] and [3], i.e. ${ }^{*}-i h_{2}-/-i e h_{2}$ - for feminine nouns, ${ }^{*}$-ies- - -ios- for comparative forms of adjectives, and ${ }^{*}-i e h_{1}-/-i h_{1}-$ for the athematic optative mood, seem to belong to very old phase of PIE (in chronological relative terms), due to their formal and functional traits. Although Rieken does not develop theoretically this approach, I think that this is a very interesting way to focus the problem: in contrast to the highly speculative and scientifically unfounded use of absolute chronologies for establishing if something is more or less 'archaic' (see above $\$ 6$ ), relative chronology is a methodologically safe tool that can play an important role for deciding if the absence of a category —and the morphemes that represent it is due to a loss or to an early separation. The fact that there are very clear proofs that Proto-Anatolian inherited a fully developed thematic stem formation both in verbs and in nouns makes it difficult to assume that Anatolian separated before the development of an optative characterized by an athematic and therefore clearly archaic suffix such as ${ }^{*}-i e h_{1}-/-i h_{1}-$.

Given the scarce amount of innovations not shared by Anatolian, Rieken clearly chooses the second option of the dilemma above, i. e., she concludes that an early separation must be ruled out 
and other alternative solutions must be preferred. In this sense, Rieken points to the possibility of contact induced changes that would "simplify" Anatolian.

Although Melchert (forthcoming) claims that Rieken (2009) recognizes fewer "Indo-Hittite" features than himself, actually Melchert adduces only four phenomena as "guaranteed" common post-Anatolian innovations which are due to the creation or loss of functional categories: [a1] the feminine gender ("almost certainly"), [a2] the participles with fixed diathesis (against the Anatolian - nt-participles, which are indifferent to diathetic distinctions) ("arguably"), and [a3] the perfect ("perhaps"), [a4] the loss of collective plural as a living category ("likely"). To these he adds the changes in the formal expression of categories, i.e. the creation of new morphemes for existent categories. He enumerates six such cases, the latter two being more doubtful: [b1] the renewal of the dat. pl. ending *-os, [b2] the replacement of the pronominal nominative-accusative neuter plural ending ${ }^{*}$-o $i$ by the nominal ending - $e h_{2}$, [b3] the loss of the ${ }^{*} h_{2} e$-conjugation, [b4] the expansion of "simple" thematic verbal stems, [b5] development of the fully sigmatized aorist, and finally [b6] the loss of embedded relative clauses.

In these traits we can recognize the corresponding versions of four traits in Rieken's list above: $[\mathrm{a} 1]=[1],[\mathrm{b} 1]=[4],[\mathrm{b} 3]=[6],[\mathrm{b} 5]=[5]$. As for Rieken's two remaining traits, namely, [2] adjectival gradation and [3] optative and subjunctive moods, Melchert says nothing about [2], while, as for [3], he assumes as probable that Proto-Anatolian did have both verbal categories but later lost them.

$\$ 9$. A clear conclusion can be drawn from Rieken's and Melchert's studies: the two main points of discussion about the position of Anatolian are the feminine gender and the hi-conjugation. The remaining features can be accounted for by both the "Schwund"- and 'early separation'-hypotheses once these two points will have tipped the balance in favor of either hypothesis.

Unfortunately, in my opinion it is not still possible to give preference to one or another hypothesis in either case.

The lack of feminine gender in Anatolian was in principle one of the strong arguments in favor of an early separation. The fact that Hittite had only a neuter and a "common" gender and that it did not have a differentiated stem class coming from PIE stems in *-eh (the most characteristic feminine stems in the proto-language) was combined with the idea that in the Brugmannian PIE, the feminine gender was a recent category on the basis of internal reconstruction. It must be stressed, however, that this second idea is not properly an argument, because it does not serve to state that the emergence of feminine gender is more recent than an alleged early separation of Anatolian. Note the clear risk of circularity of the argument: Anatolian is said to have separated from PIE because it lacks the "recent" category feminine, and feminine is a very recent category in PIE because PIE developed it after the separation of Anatolian.

An important argument in this discussion is the fact noted above that Lycian conserved a stem class in $-a$ from ${ }^{*}-e h_{2}$ which is formally different from the thematic class, characterized in Lycian by the - $e$ - vowel derived from PIE ${ }^{*}-o$-, secondarily converted in -e/i-for non neuters, due to the so-called $i$-mutation [on this see Rieken 2005). Melchert has tried to find clear remnants of a differentiated category of feminine in this Anatolian dialect, which would lead us to definitively conclude that the absence of feminine gender in Anatolian was due to a loss (Melchert 1994). Nevertheless, Melchert only found a possible, but very doubtful example of feminine agreement. In a later analysis of the Lycian $a$-stems, Ivo Hajnal (Hajnal 1994) has demonstrated that these stems were not specialized in the expression of feminine referents, and this led (forthcoming) to change his first views, in particular to dismiss his previous proposal of a case of feminine agreement in Ly- 
cian and to accept that "the development of the feminine gender [is] a common innovation of the non-Anatolian Indo-European languages."

In my opinion, however, the two arguments that seem to have persuaded Melchert for his new view, i.e. the lack of agreement and the non-specialization as feminines of the $a$-stems in Lycian, do not inevitably lead to the conclusion that feminine gender is a post-Anatolian development. The first argument is per se insufficient: non-agreement is equally explainable as a loss of a category (note the disappearance of feminine - and neuter- in English) or as an archaism. The second argument is also weak. It seems to assume an absolute identification between ${ }^{*}-h_{2}$ and the expression of the feminine motion in PIE. The things, however, are not so clear. Matasović (2004) has observed that the true feminine nouns in ${ }^{*}-e h_{2}-\left(\right.$ and even in $\left.{ }^{*}-h_{2}\right)$ that can be reconstructed for PIE are very scarce. This points to the idea that the productive character of this suffix as the marker of feminine referents developed at a post-Indo-European phase, i.e. in the particular development of each language and in a parallel and independent way. It is therefore perfectly possible to assume that Proto-Anatolian inherited the feminine gender, and that it lost this category before the generalized use of ${ }^{*}-e h_{2}$ (> Proto-Anatolian ${ }^{*}-\bar{a}$ ) for feminine motion occurred. This explanation allows us to see the Lycian state of affairs from a different perspective: not as the situation previous to the development of feminine gender category (as in Adiego 2013), but rather as the situation following the loss of the feminine grammatical gender. As a result, the Lycian $a$-stems belonging to the common gender contained nouns for inanimate referents ( $\chi$ upa 'tomb'), nouns for feminine referents (kbatra 'daughter', lada 'wife', $\chi$ ñna 'grandmother') and nouns for masculine referents ( $\chi$ uga 'grandfather,

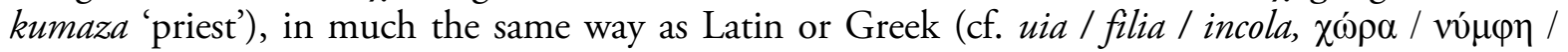
$\left.v \varepsilon \alpha v^{\prime} \bar{\alpha} \varsigma\right)$. Differently to these languages, the loss of the feminine gender already in Proto-Anatolian did not favor the specialization of Lycian $a$-stems for feminine referents.

We have then two alternative scenarios for explaining the coexistence of $a$-stems and lack of feminine agreement in Lycian: this can reflect either the consequence of an early separation of Anatolian, preceding a common post-Anatolian emergence of feminine gender, or the result of a loss of feminine gender in Anatolian that prevented a further specialization of $a$-stems as prototypical feminine motion stems. It seems very difficult to choose one scenario in preference to the other.

Things are even more complicated in the case of hi-conjugation. There is a general consensus regarding the close relationship between the endings of Hittite hi-conjugation and the endings that we can reconstruct for Brugmannian PIE perfect. The problem is how to articulate this relationship in a convincing model of PIE reconstruction, and in this sense, neither 'early-separation' nor 'Schwund'-hypothesis seem to have been able to elaborate such a model. Both approaches must assume strong transformations: unlike the feminine problem, where the question is the absence of a category that must be explained either as a non-developed category or as the loss of an existing category, the fact that a similar set of verbal endings serve for the expression of different categories (an aspectual class in Brugmannian PIE, a complete system of present-preterit in Hittite) seems to call for more complex explanations. On the one hand, defenders of the 'Schwund'hypothesis must assume that, in the diachronic development that goes from PIE to Hittite, some reduplicated perfects lost both their reduplication and their original stative meaning, giving rise thus to a new conjugation system. This new conjugation system spread then to other verbs without any clear semantic basis. On the other hand, followers of the 'early separation'-hypothesis, insofar as it is difficult to see the Hittite hi-conjugation as a direct reflect of a previous phase of the PIE perfect, are forced to reconstruct a new category from which both post-Anatolian perfect and Hittite hi-conjugation must be derived. 
To complicate matters, though our knowledge of the conjugation system of the remaining Anatolian languages is deficient, what we know about these dialects points to a system which was not exactly coincident with that of Hittite. As a consequence, the direct comparison of Hittite to Brugmannian PIE without a previous reconstruction of the state of affairs in Proto-Anatolian can be considered a temerity.

$\$ 10$. A century after Hrozný foundational work on the Indo-European character of Hittite, the problem of the position of the Anatolian group inside the IE language family continues to be unresolved. The dispute between two main hypothesis — the 'Schwund'-hypothesis and the 'early separation'-hypothesis - is still alive.

The progress in the study of Anatolian dialects other than Hittite has undoubtedly enriched our knowledge of the linguistic situation of Asia Minor in the Antiquity, but their contribution to the topic analyzed in the present article is confusing. On the one hand, it has become clear that we cannot project to Proto-Anatolian all Hittite features and reduce the problem to a comparison between (Brugmannian) IE and Hittite. On the other hand, the scarcity of documentation of these Anatolian dialects makes it difficult to go beyond the questioning of conclusions based exclusively on Hittite data.

As we have seen, recent works by Rieken and Melchert have reduced the number of possible common innovations occurred at a post-Anatolian Indo-European linguistic stage, an assumption which would allow us to speak of an early separation of Anatolian group. As a result, the discussion on the position of Anatolian virtually focuses on two Anatolian points, namely, the lack of feminine gender and the hi-conjugation. In my opinion, there is no way to give preference to one hypothesis over the other.

\section{REFERENCES}

Adiego, I. X., 2007, The Carian Language, Leiden-Boston: Brill.

—, 2012, "Minima Pisidica: nota sobre la estructura de una inscripción pisidia de Timbriada», in V. Orioles (ed.), Per Roberto Gusmani: studi in ricordo, 2. Linguistica storica e teorica, Udine: Forum, 17-26.

—, 2013, "Gènesi i evolució de la categoria de gènere en indoeuropeu», Caplletra. Revista internacional de filologia 54, 159-177.

Bozzone, C., 2012, «The PIE Subjunctive: Function and Development», in H. C. Melchert (ed.), The Indo-European Verb. Proceedings of the Conference of the Society for Indo-European Studies, Los Angeles 1315 September 2010, Wiesbaden: Reichert, 7-18.

Brixhe, C., 1988, «La langue des inscriptions épichoriques de Pisidie», in Y. L. Arbeitman (ed.), A Linguistic Happening in Memory of Ben Schwartz, Louvain la- Neuve: Peeters, 131-155.

Brugmann, K., B. Delbrück, 1886-1900, 1897-1916, Grundriß der vergleichenden Grammatik der indogermanischen Sprachen, First and Second Edition, Strassburg: Trübner.

Carruba, O., 1970, Das Palaische. Texte, Grammatik, Lexikon, Wiesbaden: Harrasowitz.

$\mathrm{CHD}=$ H. G. Güterbock, H. A. Hoffner, Th. P. J. van den Hout, Chicago Hittite Dictionary, Chicago: Chicago University Press, 1975-.

Dercksen, J. G., 2007, «On Anatolian Loanwords in Akkadian Texts from Kültepe», Zeitschrift für Assyrologie und vorderasiatische Archäologie 97, 26-46.

Forrer, E. O., 1919, «Die acht Sprachen der Boghazköi-Inschriften», Sitzungsberichte der Preussischen Akademie der Wissenschaften, Jahrgang 1919, LIII, 1029-1041.

—, 1921, "Ausbeute aus den Boghazköi-Inschriften», Mitteilungen der Deutschen Orient-Gesellschaft 61, 2039. 
Gerard, R., 2005, Phonétique et morphologie de la langue lydienne, Louvain-La-Neuve: Peeters.

Gusmani, R., 1964-1986, Lydisches Wörterbuch, Heidelberg: Winter.

Hajnal, I., 1994, "Die lykischen a-Stämme: Zum Werdegang einer Nominalklasse», in J. E. Rasmussen (ed.), In honorem Holger Pedersen. Kolloquium der Indogermanischen Gesellschaft vom 26. bis 28. März 1993 in Kopenhagen, Wiesbaden: Reichert, 135-171.

Hawkins, J. D., 2000, Corpus of Hieroglyphic Luwian Inscriptions, Volume I: Inscriptions of the Iron Age. Parts 1, 2, and 3, Berlin: de Gruyter.

Hawkins, J. D., A. Morpurgo-Davies, G. Neumann, 1973, «Hittite Hieroglyphs and Luwian. New Evidence for the Connection", Nachrichten der Akademie der Wissenschaften in Göttingen. I. PhilologischHistorische Klasse 1973/6, 143-197.

Hoffner, H. A., H. C. Melchert, 2008, A Grammar of the Hittite Language, Winona Lake: Eisenbrauns.

Houwink Ten Cate, Ph. H. J., 1965, The Luwian Population Groups of Lycia and Cilicia Aspera during the Hellenistic period, Leiden: Brill.

Hrozný, F., 1915, «Die Lösung des hethitischen Problems», Mitteilungen der Deutschen Orient-Gesellschaft 56, 17-50.

—, 1917, Die Sprache der Hethiter. Ihr Bau und ihre Zugehörigkeit zum indogermanischen Sprachstamm, Leipzig: Hinrichs.

HW = J. Friedrich, A. Kammenhuber, Hethitisches Wörterbuch, Heidelberg: Winter, 1984- (2nd edition). Jasanoff, J., 2003, Hittite and the Indo-European Verb, Oxford-New York: Oxford University Press.

Kalınka, E., 1901, Tituli Asiae Minoris I: Tituli Lyciae lingua Lycia conscripti, Vienna: Alfred Hoelder.

Kloekhorst, A., 2008, Etymological Dictionary of the Hittite Inherited Lexicon, Leiden-Boston: Brill.

Kretschmer, P., 1896, Einleitung in die Geschichte der Griechischen Sprache, Göttingen: Vandenhoeck \& Ruprecht.

Knudtzon, J. A., 1902, Die zwei Arzawa-briefe. Die ältesten Urkunden in indogermanischer Sprache, Leipzig: Hinrichs.

Laroche, E., 1957-58, «Comparaison du louvite et du lycien [I]», Bulletin de la Société Linguistique de Paris 53, 159-197.

—, 1960, "Comparaison du louvite et du lycien [II]», Bulletin de la Société Linguistique de Paris 55, 155185.

—, 1966, Les noms des hittites, Paris: Klincksieck.

—, 1967, "Comparaison du louvite et du lycien [III]», Bulletin de la Société Linguistique de Paris 62, 46-66.

Matasović, R., 2004, Gender in Indo-European, Heidelberg: Winter.

Melchert, H. C., 1994, "The Feminine Gender in Anatolian», in G. Dunkel et al. (eds.), Früh-, MittelSpätindogermanisch. Akten der IX. Fachtagung der Indogermanischen Gesellschaft vom 5. bis 9. Oktober 1992 in Zürich, Wiesbaden: Reichert, 231-244.

—, 1998, "The Dialectal Position of Anatolian within Indo-European», in B. Bergen et al. (eds.), Proceedings of the 24th Meeting of the Berkeley Linguistics Society, Special Session on Indo-European Subgrouping and Internal Relations, 24-33.

—, 2001, Lycian Corpus (last modified 7/6/01): http://www.linguistics.ucla.edu/people/Melchert/lyciancorpus.pdf (last access: 11/2015).

—, 2003 (ed.), The Luwians, Leiden-Boston: Brill.

—, 2004a, A Dictionary of the Lycian Language, Ann Arbor: Beech Staves Press.

—, 2004b, «Lycian», in R. D. Woodard (ed.), The Cambridge Encyclopedia of the World's Ancient Languages, Cambridge: Cambridge University Press, 591-600.

—, 2004c, «Lydian», in R. D. Woodard (ed.), The Cambridge Encyclopedia of the World's Ancient Languages, Cambridge: Cambridge University Press, 601-608.

—, 2013, «Naming Practices in Second and First Millennium Western Anatolian», en R. Parker (ed.), Personal Names in Ancient Anatolia, Oxford, 31-49.

—, forthcoming, "The Position of Anatolian», in M. Weiss, A. Garrett (ed). Handbook of Indo-European Studies (to appear). 
Neumann, G., J. Tischler, 2007, Glossar des Lykischen, Wiesbaden: Harrasowitz.

Nolle, J., 2001, Side im Altertum. Geschichte und Zeugnisse. Bd. 2, Bonn: Habelt.

Pedersen, H., 1945, Lykisch und Hithitisch, Kobenhavn: I kommission hos Munksgaard.

Pérez Orozco, S., 2007, «La lengua sidética. Ensayo de síntesis», Kadmos 46, 125-142.

Punvel, J., 1984-, Hittite Etymological Dictionary, Berlin-New York- Amsterdam: de Gruyter.

Rieken, E., 2005, "Neues zum Ursprung der anatolischen i-Mutation», Historische Sprachforschung 118, 48-74.

—, 2009, "Der Archaismus des Hethitischen; eine Bestandsaufnahme», Incontri Linguistici 32, 37-52.

SaYce, A. H., 1877, "On the Hamathite inscriptions», Transactions of the Society of Biblical Archeology 5, 22-32.

Sturtevant, E. H., 1926, «On the Position of Hittite among the Indo-European Languages», Language, Vol. 2, No. 1, 25-34.

Szemerényi, O. J. L., 1996, Introduction to Indo-European Linguistics, Oxford: Oxford University Press, translated from Einführung in die vergleichende Sprachwissenschaft 4th edition, Darmstadt, 1991.

Tischler, J., 1977-, Hethitisches Etymologisches Glossar, Innsbruck: IBS.

Tischler, J., G. F. Del Monte, 1978, Die Orts- und Gewassernamen der hethitischen Texte, Wiesbaden: Reichert.

Trudgill, P., 2010, Investigations in Sociohistorical Linguistics, Cambridge: Cambrdige University Press.

Yakubovich, I., 2010, Sociolinguistics of the Luvian Language, Leiden-Boston: Brill.

Zeilfelder, S., 2001, Archaismus und Ausgliederung. Studien zur sprachlichen Stellung des Hethitischen, Heidelberg.

Zgusta, L., 1964, Kleinasiatische Personennamen, Prag: Verlag der tschechoslowakischen Akademie der Wissenschaften.

—, 1971, Neue Beiträge zur kleinasiatischen Anthroponymie, Prag: Academia.

—, 1984, Kleinasiatische Ortsnamen, Heidelberg: Winter. 